\title{
The promise of curriculum in the post-Covid world: Eclecticism, deliberation, and a return to the practical and the prophetic
}

\author{
James P. Burns ${ }^{1}$ (D) Christopher Cruz $^{1}$ (D)
}

Accepted: 27 December 2020 / Published online: 26 January 2021

(C) UNESCO IBE 2021

\begin{abstract}
This article focuses on the possibilities through which curriculum on the other side of the Covid-19 pandemic might contribute more proactively to future social and political crises that are multifarious yet interconnected in nature. The Covid-19 pandemic is a global crisis that touches every aspect of social life, including politics, the economy, healthcare systems, poverty, forced human migration, climate change, and importantly, education. To potentially address future crises through curriculum, the article first problematizes the present in education and society-specifically, the 50-year neoliberal project that has transformed society and education. It connects the crisis in education to a transformed social, political, and economic system that has introduced what Gordon Lafer has called a revolution of falling expectations through a hollowing-out of public institutions. The article then returns to the crisis of curriculum, contextualized in Joseph Schwab's The Practical: A Language for Curriculum, which presaged the reconceptualization of the curriculum field. It dialogues with Schwab's advocacy for an eclectic, deliberative, and practical curricular ethic as a form of post-reconceptualization curriculum study to contribute to understanding and managing future disruptions, such as those inevitably associated with the climate crisis. Finally, the article connects to the concept of liquidity in curriculum, through which to embody curricular eclecticism and provoke teachers and students to author a vision for a more just future that will not reinscribe the pathologies of the past.
\end{abstract}

keywords Curriculum theory $\cdot$ Covid-19 $\cdot$ Joseph schwab $\cdot$ Self-cultivation $\cdot$ Social inequity

James P. Burns

jburns@fiu.edu

Christopher Cruz

ccruz013@fiu.edu

1 Department of Teaching and Learning, Florida International University, 11200 SW 8th St., MMC, ZEB 257A, Miami, FL 33199, USA 
Throughout the world, communities, governments, and institutions-notably schools, colleges, and universities - continue to confront the Covid-19 pandemic. As of December 18, 2020, the Johns Hopkins University School of Medicine Coronavirus Resource Center (2020) reports over 75 million Covid cases and more than 1.6 million deaths globally. The United States, with approximately five percent of the world's population, accounts for over 17 million Covid cases and more than 300,000 deaths. Institutional unpreparedness for a foreseeable public health emergency has starkly illuminated a myriad of preexisting social, political, economic, and educational disparities, the consequence of conscious policy decisions undertaken in support of the long-term neoliberal project.

In the midst of a global public health crisis, the nearly religious elite discourse of the economy über alles has even further marginalized the voices of those rendered superfluous to the plutocratic class: precariously employed "essential" workers, the impoverished, the elderly, children, the incarcerated, refugees, and even the earth itself. While 50 years of neoliberal capitalism may not have caused the Covid pandemic, the purposeful weakening of public institutions has severely impeded a comprehensive response, as demonstrated by the human toll thus far. The pandemic provokes existential curricular questions about the conditions that led to a systematic failure to address a predictable global public health crisis, including related crises of unemployment, eviction, health and educational disparities, and equity issues related to the development and distribution of a vaccine.

Although we might say that neoliberalism did not cause Covid-19, the pandemic and the faltering responses to it have made numerous widening inequities, institutional violence, and the politics of disposability inherent in neoliberal capitalism more visible. Perhaps the "new" perspectives that Covid brings to curriculum studies might be the provocation to inquire into the confluence of extreme disparities - health, racial, class, gender, educational, environmental - that make even more visible the multifarious existential threats that we as a species face and the inadequacies of our political and social systems to address them. Curriculum might thus form generative spaces to understand and act on a new ethics of being with each other and the natural world.

Amid the largely inept response to Covid by the US government, President Trump has deployed the "big lie"- a propaganda technology we currently call post-truth. The term post-truth, however, was first coined by playwright Steve Tesich (1992) in an article in The Nation titled "A Government of Lies". Discussing the first Iraq War and Iran-Contra, Tesich (1992) prophetically concluded that Americans had "acquired a spiritual mechanism that can denude truth of any significance" and noted that awaiting the US would be a "monster with a human face...to inform us with whom we have been collaborating" ( $p$. 14). President Trump has used the big lie to foment a milieu in which, notes Hett (2018), writing of the death of democracy and the downfall of Weimar Germany, facts don't matter. Hett (2018) contextualized his analysis of the big lie in Adolf Hitler's extensive writings on propaganda in Mein Kampf, particularly, the manipulation of language, the repetition of increasingly outrageous truth claims, and the targeting of numerous Others. Despite the repugnance of Hitler and other fascist leaders, to ignore their writings as historical documents, particularly during an era defined by resurgent authoritarianism, would be to perpetuate the very ahistoricism that has impeded our transcending the problems of the present. Indeed, Pinar (2019, p. 3) warns against discarding a past "that does not serve present preoccupations" and asks: "How would one know what might serve the present unless one has studied the past?"

As a political tactic, the big lie sows divisiveness, distrust, panic, and public confusion. During the Covid pandemic, President Trump and other authoritarian leaders have employed post-truth discourses to blame various "outsiders", marginalized peoples, and 
the political left; to foment conspiracy theories about the pandemic; and to effect militaristic assaults on political dissent, including persistent claims of "left-wing indoctrination" in education. President Trump, who himself was hospitalized on October 2, 2020 after contracting Covid, consistently minimized the danger of the pandemic as fake news and fueled various conspiracy theories related to the virus. The president has also encouraged protests-notably an armed occupation of the Michigan State Capitol— to "reopen America".

The pandemic, and the big lie that has framed various discourses about it, reveals the fundamental relationship between power and impotence, which "complement and reinforce each other in a kind of fascinating satisfaction that is found above all in the most mediocre Statesmen...For they extract glory from their shortsightedness and power from their impotence" (Deleuze and Guattari 1987, p. 225). Not only do right-wing populists have a problematic history of revolting against the public to the detriment of the broader demos; liberal elites, as Lasch (1996) reminds us, fearful of the loss of their institutional privilege, do as well. Elite revolts enjoy an ignominious history in US education, conjoined with the social engineering function of the school that we have been "reluctant to abandon" (Pinar 2006, p. 109). A reckoning with the social, political, economic, and educational past through curriculum studies and theorizing is crucial to self and social reconstruction, particularly during a pandemic, which, as Camus (1991) noted, will inevitably return both as the bane of humanity and to enlighten us.

As has often been the case in the past, schools and society have greeted present crises as unprecedented new phenomena. The short horizon of historical understanding is unsurprising in a milieu characterized by social, political, and educational discourses flattened onto an ahistoric "never-ending now" (Pinar 2012, p. 227). The Covid pandemic thus starkly highlights the complexities of human and environmental well-being as a crucial curricular issue. We undertake our inquiry into the potential of curriculum amid a global pandemic in the spirit articulated by Camus (1991): to not hold our peace but instead bear witness to this historical moment, connect seemingly disparate struggles to resuscitate an imperiled global democratic project, illuminate both institutional failures and the best of humanity, pursue truth, and imagine a more just future. Camus (1991) captured a critical aspect of curriculum, particularly in times of crisis, in writing of Dr. Rieux in the conclusion of The Plague:

Nonetheless, he knew that the tale he had to tell could not be one of a final victory. It could be only the record of what had had to be done, and what assuredly would have to be done again in the never-ending fight against terror and its relentless onslaughts, despite their personal afflictions, by all who, while unable to be saints but refusing to bow down to pestilences, strive their utmost to be healers. (p. 308)

Camus articulates several tenets of post-reconceptualization curriculum scholarship, such as the historicization of the present, witnessing, the hermeneutic of the subjective and the social, and an ethic of care for others and the world.

\section{Covid and the educational problem of the present}

Curriculum studies exists in a historical moment characterized by both resurgent authoritarian populism in the midst of a global pandemic and a reconceptualized field. That field has opened numerous trajectories into curricular study and theorization across academic disciplines, cultural contexts, and national borders. Further, instrumental schooling in 
the US exists amid a persistent false choice between theory and practice, the product of a national history of anti-intellectualism and devotion to the "practical effects of the business-minded" (Pinar 2006, p. 110). The promise of curriculum, particularly as the international community navigates the Covid crisis, lies in the potential enactment of curriculum as a complicated conversation that investigates the intersected social, political, economic, educational, and environmental issues illuminated by the pandemic itself. For example, curriculum could inquire into the failure of nation-states, enthralled to the logics of neoliberal capitalism, to prepare for a predictable crisis; the health and economic disparities among those most affected by the pandemic; and the politics of disposability made increasingly visible in the context of mass incarceration, precarious employment, and the treatment of refugees. We also urge speaking sparingly of schools (Pinar 2004), particularly as decades of corporate school "reform" have magnified the historic impulse to forefront the school as the indispensable site of social engineering. To speak of education, which can and often does occur in schools (Pinar 2004), is to recognize, as the Covid pandemic illustrates, that the sites and material questions that might comprise curriculum as complicated conversation exist all around us. The proactive possibilities of curriculum in the wake of this pandemic lie in opportunities to situate ourselves socially, historically, and internationally and provoke dialogue and action regarding issues of crucial importance to education and society that Covid has made visible.

For example, the increased atomization of public institutions into private spaces of consumption has fueled authoritarian discourses such as those associated with the radical religious right (Hedges 2006; Stewart 2019). In the US, authoritarian populism (Apple 2006) is embedded in Secretary of Education Betsy DeVos's mission to reconfigure school spaces to advance "God's kingdom" (Rizga 2017). For DeVos, and those who share her theocratic vision, the long-term strategy lies in redirecting funding away from public education and toward charter and private schools through voucher legislation marketed with the language of choice, empowerment, equity, freedom, and civil rights (Armiak 2019; Kumashiro 2008). The Covid pandemic has illuminated the role of Christian nationalism in science denial and a broader "life-threatening belief in the privatization of everything" (Stewart 2020, para. 10). Thus, curriculum in the context of the Covid pandemic could inquire into Christian nationalism as a political ideology and its impacts on education and society.

Another area of curriculum study evoked by Covid relates to existing racial disparities, partially a product of corporate school reforms, that have been further exacerbated by the pandemic. The expansion of charter schools, school choice, and educational accountability legislation and policies historically targeted at "underperforming" schools in urban and rural communities of color-post-Katrina New Orleans is a particularly egregious example-typically produce and reinforce existing segregation (Kumashiro 2008, 2012; Lafer 2017). During crises such as Covid, schools and other social institutions are susceptible to the introduction of increasingly onerous disciplinary technologies, which have overwhelmingly targeted historically subjugated communities (Klein 2007). Racial disparities in education made increasingly visible by Covid are also imbricated with histories of housing discrimination (Taylor 2019) racist policing (Vitale 2017), and a judicial system that has produced mass incarceration and codified numerous forms of inequality (Cohen 2020; Rothstein 2017).

Schools have also responded to the Covid pandemic by migrating schooling onto computer screens in family living rooms, which has increased segmentation of the public sphere into our private homes for the sake of returning to normal. Nothing about this pandemic is normal, and we do not advocate for a return to the normality that existed prior to Covid-19-rampant economic and political inequality, growing racial 
and anti-immigrant violence, militarism, mass surveillance, propaganda, environmental degradation, and health disparities. The desire to return to such a world illustrates the "gracious submission" (Pinar 2004) of many in the education field to the neoliberal worldview, which threatens, once again, to reinscribe the past on the future. The melancholic desire for normalcy blunts the scholar's "prophetic" edge and thus ceases to be hopeful (Freire 2005). The desire for a return to normal also reflects a revolution of falling expectations (Lafer 2017), which has habituated many throughout the world to consider their increasingly precarious lives as normal. The tragedy of a post-Covid world would be a future that returns to the material conditions of the past, and a crucial aspect of curriculum study and theorizing in this moment is its contribution to transcending the present. Increasingly complex inquiry into commonsense discourses of "normality", including assertions that the disruptions to our lives caused by Covid are "the new normal", may be one of the more important aspects of curriculum theorizing provoked by the pandemic.

In the wake of the Covid pandemic, curriculum could fundamentally question the desirability of returning to pre-Covid "normality". For example: What has the pandemic revealed about deteriorating social, material, educational, and political conditions and the militarized corporate state? Whose interests have national governments moved to protect, and whose have been further marginalized? How should a vaccine be developed and distributed globally? How has the international community succeeded and failed to cooperate regarding the pandemic? To what extent have we accepted as "normal" the social and material conditions tied to capitalism's boom and bust cycles? How should we respond to discourses of a "new normal" in education that might lead to its further outsourcing?

Too often, education discourses reflect a social attitude that has largely ceased to engage with the tensions of the world and failed to recognize that "reality cannot be resolved into the thinkable" (Moran and Mooney 2002, p. 360). Instrumental schooling diminishes the space for reflexive thinking, which can neither be relegated to, nor adequately reflected in, assessments. How can curriculum scholars speak sparingly of the school and imagine educational spaces in which to engage in study and reflexive thinking? Education discourses have been predominantly about school. Curriculum as enacted in schools, however, continues to be decontextualized and prescribed for students as standardized behavioral objectives, which prioritize knowledge and skills that possess a market value. Consistent with the tradition of the reconceptualization, we advocate for a renewed study of curriculum, both inside and outside the school, to open spaces for contemplation and self-exploration. By also considering curriculum outside the classroom, such a study extends into curricular spaces of contemplation and reflection that have significance for a much wider vision of understanding, one that is shaped not only by economic concerns. These concerns may have social, global, and perhaps, in some theological traditions, cosmic significance. This is not to say that curriculum is not found within classrooms, of course. It is simply to suggest that the scope of our investigations not be narrowed by the consistent conflation of schooling and education.

The struggles over and questions concerning curriculum, like the social and political crises we face, also emerge in historical context, which is often lacking in analyses of present problems. To historically situate the present question of curriculum as it relates to the Covid pandemic, we thus return to the crises of curriculum of which Schwab (1969) wrote. Our return to Schwab's analysis is, as Pinar (2019) suggests, necessary to take up the prophetic aim of demonstrating how reactivating the past informs our understanding of the conditions of possibility that have yielded the material conditions of the present. 


\section{A return to the past: Schwab and the crises in curriculum}

A return to the past need not lead to its romanticization. The regressive step in the curriculum studies method of currere (Pinar 2012) situates one socially and historically, and in that spirit, we return to Schwab's (1969) analysis of the various "flights" that constituted the crisis of curriculum of that time and his conclusion that the curriculum field's renaissance would require a turn to the "practical, the quasi-practical, and the eclectic" (p. 1). As we discuss below, we see many of the "flights" to which Schwab (1969) referred in contemporary education discourses. We engage with Schwab (1969) to evoke dialogue among curriculum scholars, teachers, students, and others interested in a more proactive curricular orientation to the multifarious existential issues that confront the world, which the Covid pandemic has made starkly visible.

Schwab's (1969) suggestion that the curriculum studies field move away from the theoretical and toward the practical does not discount the importance of theory in curriculum studies. Rather, he critiqued the grand yet particular theories that have structured our thinking about education and society, theories that have historically originated in the social and behavioral sciences. Notable among them is the persistent Tyler rationale (1949), obsessed with learning objectives derived from analyses of students' needs—read "deficiencies"subsumed under assessment and predicated on a disciplinary vision of education as the manipulation of observable behaviors. Similarly, Schwab's (1969) understanding of the practical did not mean the "curbstone practicality of the mediocre administrator" but a "complex discipline, relatively unfamiliar to the academic and differing radically from the disciplines of the theoretic" (p. 1). Schwab (1969) advocated for an eclectic form of curriculum inquiry in which an "unsystematic, uneasy, but usable focus on a body of problems is effected among diverse theories, each relevant to the problems in a different way" ( $p$. 1). In the case of Covid, the theoretical-practical promise of curriculum lies, as Schwab (1969) suggested, in the arts that discern between reality and its theoretical representation, that continually retheorize according to the discrepancies encountered, and that account for aspects of reality unaccounted for by theory.

\section{Crises and flights}

The signs of crisis Schwab noted in the curriculum field resonate today, particularly considering the conflation of standardized objectives and curriculum. Because a full discussion of Schwab's (1969) analysis exceeds the scope of this article, we situate our present inquiry in the most relevant aspects of his articulation of the curriculum field's signs of crisis as six flights. First, Schwab (1969) perceived a "flight from the field itself", reflected in a "translocation" of curriculum to others. In other words, curricular issues and decision making have been relocated to those outside the curriculum field. In the present era of neoliberal corporate school deform (Pinar 2012), for example, teachers and their students have been rendered nearly superfluous in the co-creation of curriculum. The activities in schools, to the extent they can be considered curriculum, have been essentially outsourced to textbook publishers, testing companies, app developers, and a billionaire boys club (Ravitch 2010) of libertarian philanthrocapitalists who seek to remake schools in the image of corporate America. The increased turn to politically unaccountable impact investors, thought leaders, and self-appointed change agents (Giridharadas 2018) illustrates the 
historic social engineering function of schooling, now delivered with the promise of parent and student empowerment, choice, and liberty while also holding teachers accountable for student success as reflected in standardized test scores (Pinar 2012; Taubman 2009).

The second upward flight "from discourse about the subject of the field to discourse about the discourse of the field" (Schwab 1969, p. 4) reflects an obsession with the construction of models, metatheory, and theories of management. Curriculum development models such as Understanding by Design (UbD; Wiggins and McTighe 2005), which are taught as "revealed doctrine" (Kliebard 1970, p. 259) in teacher education programs, provide a contemporary example of the enthrallment to models of standardization derived from the Tyler rationale. UbD, which restates the Tyler rationale nearly verbatim, relies on a linear process, including setting objectives, determining "acceptable evidence" of student understanding, and planning "learning experiences" (Wiggins and McTighe 2005, pp. 17-18). The goal of curricular metatheory, as expressed in $\mathrm{UbD}$, fits with the corporate logic of "scaling solutions" - create a model in a local context, then scale it to the general education system.

Third, the downward flight represents "an attempt by practitioners to return to the subject matter in a state of innocence, shorn not only of current principles but of all principles", to look completely anew at subject matter (Schwab 1969, p. 4). While disenthralling ourselves from certain practices may be productive, such efforts can risk further de-historicizing curriculum and falling victim to educational restoration discourses such as calls to get "back to basics" and, more ominously, the radical Evangelical attempt to reconfigure schooling as part of a larger theocratic institution. Fourth, the flight to the sidelines as observers and critics may serve a purpose, but as Pinar (2011) warns, critics risk falling into the role of objectifying observers who fail to wrestle with their own situation in history and culture.

Fifth, "marked perseveration" consists of the "repetition of old and familiar knowledge in new languages which add little or nothing to the old meanings...or repetition of old and familiar formulations by way of criticisms or minor additions and modifications" (Schwab 1969, p. 4). Persistent formulations such as the Tyler rationale, which Kliebard (1970, p. 259) characterized as an "anachronistic dogma" kept alive by the curriculum field's lack of historical perspective, is one example of the flight of marked perseveration. Indeed, Schwab (1969, p. 6) concluded: "I recoil from counting the persons and books whose lives are made possible by continuing restatement of the Tyler rationale". The historicization of the curriculum field remains a crucial contribution of the reconceptualization. Our schools, teacher education programs, and society, however, remain problematically dehistoricized as teacher education programs remove "superfluous" topics of inquiry, such as teacher subjectivity and the historical and philosophical foundations of education, from the curriculum. Instead, teacher education has increasingly focused on the technical aspects of teaching, strategies, and best practices (Taubman 2009).

Sixth, Schwab (1969) noted the prevalence of contentious debate, both within the field and, increasingly, from outside it. Considering the current flight from the field noted above, neoliberal schooling discourses-standardization, choice, accountability, audit culture, and market logics - are now taken for granted across the political spectrum in the US and internationally. Further, the ad hominem vilification of teachers, teacher unions, teacher education, and public education more broadly has been a fundamental political strategy in the enactment of the corporate school reform agenda (Kumashiro 2012; Pinar 2012).

The flights that characterized the crisis of curriculum detailed by Schwab (1969) are similar to the contemporary crisis experienced in education, the result of corporate school deform, which the Covid pandemic's disruption of schooling, as we have come to know it, 
has made increasingly visible. Yet, just as the curriculum crisis of the late 1960s led to the reconceptualization of the curriculum studies field, so, too, might curriculum contribute differently in the wake of a complex challenge like the current global pandemic. Schwab (1969, p. 10) noted that the "uneasy, pragmatic, and uncertain unions and connections" that "can be effected in an eclectic" through a practical commitment to deliberation present a viable alternative to curriculum predicated on grand competing theories of human nature and how to manipulate it. That sense of eclecticism exists in the shifting transdisciplinarity evinced by the provocative curricular topics that comprise curriculum as deliberation-complicated conversation - as represented in new synoptic curricular texts (Pinar 2006, 2012). Schwab's (1969) eclectic and post-reconceptualization curriculum studies also remind us of Eco's (2018) application of the term liquidity to the postmodern. We conclude by turning to the concept of liquidity as a way curriculum might engage with events such as the Covid pandemic as an ethic that resonates with both Schwab's concept of the practical and post-reconceptualization curricular tenets such as subjective and social reconstruction, complicated conversation, and the question: What knowledge is of most worth? That question is, as Pinar (2019, p. 9) reminds us, the "canonical curriculum question" first posed by Herbert Spencer in 1859.

\section{The liquid society: Curriculum as an ontology of truth}

As he concluded The Plague, Camus (1991) wrote that the townspeople's cries of joy as the plague passed were imperiled. The plague bacillus, and all the other plagues that such a crisis reveals - indifference to others' humanity; anti-intellectualism; authoritarianism; corporatism; physical and institutional violence-never completely died. Rather, the plague would lie dormant, bide its time, and "for the bane and the enlightenment of men, it would rouse up its rats again and send them forth to die in a happy city" (Camus 1991, p. 308). The plague shocked the townspeople with harsh truths about themselves and the forms of social organization they accepted as normal. However, the interregnum produced by the plague also elicited humankind's most admirable attributes.

Similarly, Umberto Eco $(2018$, p. 1) characterized the "nascent present" as a "liquid society" that emerged with the postmodern fracturing of grand narratives. Postmodernism, Eco concluded, is also "on the way out", a "ferry from modernity to a present that still has no name" (Eco 2018, p. 1). The Covid pandemic exemplifies the fracturing of present grand narratives as noted by Eco: how nation-states respond to global crises; the collapse of democratic politics; the erosion of community, replaced with unbridled individualism; and consumerism. What might fill this interregnum? Where might we land as we navigate toward the yet-to-be-named present? We are certainly bearing witness to one possibility-resurgent authoritarianism, or ur-fascism, a set of existing socio-political conditions of possibility that lie dormant, like the plague bacillus, and around any one of which a "Fascist nebula will begin to coagulate" (Eco 1997, p. 78). The Covid pandemic has made the underlying pathologies of corporate authoritarianism grotesquely obvious in education and society-specifically, the cruel response to basic human needs and the suffering of so many.

During this interregnum, however, forms of community building and mutual aid in response to the failures of nation-states and their moribund political parties have also emerged. Examples of such solidarity movements include protests and legal actions to end police violence and mass incarceration, labor actions against corporations over health and safety concerns, rent strikes, and community responses to provide the 
necessities of life to those in need, all connected to or intensified by the Covid pandemic. Similarly, a liquid, eclectic, unstable, multifarious, complex, and, perhaps most important, agentive embodiment of curriculum in an equally eclectic set of sites can help children situate themselves in the context of problems of the present, both historically and socially. Perhaps the pandemic's impacts on institutionalized schooling and teacher education-the linear, gendered (Grumet 1988) practices that we take for granted-might emerge differently as we work through the Covid crisis.

The pandemic has only magnified the "sadistic stupidity" (Pinar 2012, p. 12) of teaching fragmented, decontextualized, predetermined objectives, largely technologically mediated, solely for the purpose of having the truth of being good teachers and good students extracted through endless standardized examinations. The perhaps subversive task of curriculum as we navigate Covid might be to both bear witness to the intersected social, political, economic, and educational impacts illuminated during the pandemic and highlight historical and current examples of counter-conduct against oppressive configurations of power. Curriculum can further provoke dialogic encounters and create generative spaces in which to enact a "pedagogical model of the public sphere wherein social relationships become less combative, manipulative, and selfserving, and instead, more educational" (Pinar 2006, p. 8). Those liquid dialogic spaces might help children and their teachers co-create curriculum that eclectically dances among subjects, time, and space to connect their lives with the lives of others throughout the world and develop the sense of agency necessary to reconstruct themselves and society.

The pedagogical model of the public sphere described by Pinar (2006) reflects an ontology of truth-seeking, particularly amid a global pandemic during which science denial and post-truth anti-politics are implicated in Covid-related deaths worldwide, threaten democracy, and perpetuate governmental inaction on existential issues such as climate change. It is imperative that curriculum reflect a proactive engagement with an ontology of truthtelling-parrhessia (Foucault 2011)—which enacts the relationship between the subject, the truth, and the Other. Such an ethics requires speaking one's truth and listening to others' truths, an engagement that entails personal risk in speaking one's truth and the possible discovery that one's deepest held beliefs are untrue (Foucault 2011). Truth-telling, so conceived, is a relational, thus, ethical act (Taylor 2009). We further theorize truth-telling within the tradition of confession, which reflects an understanding of confession as the recollection of the self from dispersion, always willing to bear witness to where one finds oneself. We cannot separate our experiences of the world from the classrooms we fleetingly inhabit and thus cannot understand curriculum as a set of standards. Only through the symbolic representation of experience can one come to understand oneself and the world.

It may also be helpful to understand symbolic representation as mythopoesis, from the Greek word meaning "myth making", in which myth does not constitute untruths but rather the "stories we tell that give meaning to existence" (Leonard and Willis 2008, p. 2). If education is an invitation to play with the materials one has been given, as Grumet (1993) suggests, curriculum is the substitutive art of interpreting one's own autobiographical story of educational experience (Pinar 2015). The Covid pandemic has only reinforced the desperate need for an interpretive framework to understand the world and think deeply about educational experience. Neither schools nor society were prepared for the pandemic's shock, just as they have been unable to reckon with continued crises of refugees, immigration, inequality, and climate breakdown. The work of curriculum scholars as truth-tellers, particularly in times of crisis, lies in navigating the tensions, contradictions, and paradoxes inherent in the existential challenges the world faces. 
An example of one who embodies the eclectic and agentive sense of the possibilities of curriculum and the most admirable possibilities of humankind is Greta Thunberg. Her environmental activism has educated the world on the climate crisis by connecting that existential threat with the pathologies of capitalism, consumerism, poverty, and other forms of violence against children and the species with which we share the world. Thunberg has inspired other children throughout the world to study the complexities of the climate crisis and confront government officials with their failures to act in the best interests of future generations. Similarly, Indigenous land and water protectors throughout the Americas risk their lives to pursue truth, advocate for justice, and communicate a vision for a more humane and sustainable future. That ethic of seeking and speaking truth coincides with post-reconceptualization curriculum tenets to historicize the present and imagine a future that will not simply reinscribe the past.

Thus, in the spirit of post-reconceptualization curriculum theorizing and Schwab's (1969) articulation of the eclectic and the practical, we offer some possibilities as we emerge from this pandemic that teachers, students, and others genuinely interested in unmooring curriculum, as it is too often enacted in schools, from its stultifying protocols predicated on de-contextualized objectives subsumed under standardized assessment. First, we urge curriculum scholars and teachers to forefront the question What knowledge is of most worth? That question reflects a sense of historical understanding desperately needed in education, particularly as demonstrated by the multifarious crises endemic to the Covid pandemic. And it reflects, as well, the sense of eclecticism in terms of knowledges, histories, theoretical understandings, and interlocutors with whom to deliberate in the hope of situating and resituating ourselves and our students in the social world. The Covid pandemic is imbricated with issues such as climate change, public-sector austerity, racism, poverty, authoritarianism, and capitalism that require historical engagement to both understand and transcend. Forging a global understanding of issues that affect us all also requires that the Western academy adopt considerably more humility regarding its own institutional knowledge and the regimes of truth based on that knowledge, particularly regarding the problematic narratives of perpetual progress through technological development and the destructive belief in unlimited economic growth.

Second, we urge a fundamental reassessment of the logics that underlie curriculum as enacted in schools - a linear protocol predicated on predetermined objectives, standards, and "learning experiences" that focus on preparation for standardized assessments. How might we embody curriculum not as fixed protocols but as a calling, or as what Foucault characterized as a technology of the self (see Martin et al. 1988), which Pinar (2011) explores in the context of Bildung, or self-cultivation? Curriculum as complicated conversation requires an ethic of self-care as self-cultivation to situate oneself in history and culture, contribute to social reconstruction, and resuscitate an international democratic project under assault by resurgent authoritarianism. Curricular inquiry into the Covid pandemic could provoke dialogues about global health, education, capitalism, the military-industrial complex, national and international economic inequality, history, and numerous other related topics that could invigorate academic study as a technology of the self.

Third, teachers and curriculum scholars should resist serving as modern court philosophers who rationalize the prevailing whims of institutional power (Lasch 1996). An example of a politics of refusal lies in speaking against discourses that present the Covid present as the "new normal" and political demands to further cut education funding and solidify increasingly corporatized forms of school governance with the excuse that "we have no choice", as was the case during the economic crisis of 2008. The Covid pandemic could provoke a reimagination of social organization through curriculum inquiry, which must 
engage with the past and the present to envision a future that guards against unreflectively rebranding the familiar as a revolutionary new course of action. Such historicized dialogic encounters, which investigate and propose other possibilities and different choices, would form a more proactive approach to curriculum in a post-Covid world.

Finally, we might speak sparingly of the school (Pinar 2004) in curricular discourses. As we discussed above, the obsession with the school as the site of educational activity discounts the reality that education, while it might occur in schools - and it might not—also occurs in many other places. As Arendt (1976) noted, the old world of adults is closed off to students, leading them into the tyranny of the classroom, which requires them to dispose of their subjectivities. Too often, particularly in the era of standards and assessment, teachers and children check their subjectivities at the schoolhouse door and collect them, like their raincoats, as they reenter the world. The school often exists as an abstraction to those who do not inhabit it but decide what activities occur within it.

Meeting extremely complex international issues such as Covid more proactively through curriculum requires abandoning curriculum as an instrumental technology of authoritarian demands for social engineering. The Covid pandemic suggests that reconstructing the world requires an eclectic, practical, deliberative, co-constructed curricular orientation that emerges from the subjective needs and desires of the children and teachers who briefly inhabit the school and who leave it daily to live in the social world. The knowledge learned in schools will "never suffice" and "what we undertake in the classroom is merely a hint of all that exists outside it" (Block 2004, p. 3). Curriculum can provide a glimpse of the "awe and wonder" (Block 2004, p. 3) that exists in the world, as we engage in our study of it as a lifetime vocation. Doing so would support an ethics of self and social reconstruction, an aspiration to cultivate ourselves through a lifetime of study, and a commitment to serve each other, the species with whom we share this world, and the earth itself, not as a commodity, but as our home.

\section{References}

Apple, M. (2006). Educating the "right" way: Markets, standards, God, and inequality (2nd ed.). New York, NY: Routledge.

Arendt, H. (1976). Between past and future: Eight exercises in political thought. New York, NY: Penguin Books. (Original work published in 1954).

Armiak, D. (2019, December 6). Education Secretary Betsy DeVos makes unscheduled appearance at ALEC Conference in Arizona to promote costly school voucher program. The Center for Media and Democracy's PR Watch. https://www.prwatch.org/news/2019/12/13514/education-secretary-betsy -devos-makes-unscheduled-appearance-alec-conference?fbclid=IwAR3iwCDfcXayFiYNU7jRdGe SS9JSVkHa33U3hkp8dGTJBe7NDlqjUYZAwKI

Block, A. (2004). Talmud, curriculum, and the practical: Joseph Schwab and the rabbis. New York, NY: Peter Lang.

Camus, A. (1991). The plague. New York, NY: Vintage Books. (Original work published in 1947).

Cohen, A. (2020). Supreme inequality: The Supreme Court's fifty-year battle for a more unjust America. New York, NY: Penguin Press.

Deleuze, G., \& Guattari, F. (1987). A thousand plateaus: Capitalism and schizophrenia (B. Massumi, Trans). Minneapolis, MN: University of Minnesota Press.

Eco, U. (1997). Five moral pieces (A. McEwen, Trans.). New York, NY: Harcourt.

Eco, U. (2018). Chronicles of a liquid society. New York, NY: Mariner Books.

Foucault, M. (2011). The courage of truth: Lectures at the Collège de France 1983-1984 (G. Burchell, Trans., F. Gros, Ed.). New York, NY: Picador.

Freire, P. (2005). Pedagogy of the o ppressed. New York, NY: Continuum. (First published in English in 1970).

Giridharadas, A. (2018). Winners take all: The elite charade of changing the world. New York, NY: Knopf. 
Grumet, M. R. (1988). Bitter milk: Women and teaching. Amherst, MA: University of Massachusetts Press.

Grumet, M. R. (1993). The play of meanings in the art of teaching. Theory Into Practice, 32(4), $204-209$. https://doi.org/10.1080/00405849309543599

Hedges, C. (2006). American fascists: The Christian right and the war on America. New York, NY: The Free Press.

Hett, B. C. (2018). The death of democracy: Hitler's rise to power and the downfall of the Weimar Republic. New York, NY: St. Martin's Press.

Johns Hopkins University \& Medicine (2020, September 22). Coronavirus resource center. https://coron avirus.jhu.edu/

Klein, N. (2007). The shock doctrine: The rise of disaster capitalism. New York, NY: Picador.

Kliebard, H. M. (1970). Reappraisal: The Tyler rationale. The School Review, 78(2), 259-272.

Kumashiro, K. K. (2008). The seduction of common sense: How the right has framed the debate on America's schools. New York, NY: Teachers College Press.

Kumashiro, K. K. (2012). Bad teacher! How blaming teachers distorts the bigger picture. New York, NY: Teachers College Press.

Lafer, G. (2017). The one percent solution: How corporations are remaking America one state at a time. Ithaca, NY: Cornell University Press.

Lasch, C. (1996). Revolt of the elites and the betrayal of democracy. New York, NY: State University of New York Press.

Leonard, T., \& Willis, P. (2008). Pedagogies of the imagination: Mythopoetic curriculum in educational practice. New York, NY: Springer.

Martin, L., Gutman, H., \& Hutton, P. (Eds.) (1988). Technologies of the self: A seminar with Michel Foucault. Amherst, MA: University of Massachusetts Press.

Moran, D., \& Mooney, T. (2002). The phenomenology reader. New York, NY: Routledge.

Pinar, W. (2004). What is curriculum theory? Mahwah, NJ: Lawrence Erlbaum Associates.

Pinar, W. (2006). The synoptic text today and other essays: Curriculum development after the reconceptualization. New York, NY: Peter Lang.

Pinar, W. F. (2011). The character of curriculum studies: Bildung, currere, and the recurring question of the subject. New York, NY: Palgrave Macmillan.

Pinar, W. F. (2012). What is curriculum theory? (2nd ed.). New York, NY: Routledge.

Pinar, W. F. (2015). Educational experience as lived: Knowledge, history, alterity. New York, NY: Routledge.

Pinar, W. F. (2019). Moving images of eternity: George Grant's critique of time, teaching, and technology. Ottawa, Ontario: University of Ottawa Press.

Ravitch, D. (2010). The death and life of the great American school system: How testing and choice are undermining education. New York, NY: Basic Books.

Rizga, K. (2017). Betsy DeVos wants to use America's schools to build "God's kingdom". Mother Jones. https://www.motherjones.com/politics/2017/01/betsy-devos-christian-schools-vouchers-charter-educa tion-secretary/

Rothstein, R. (2017). The color of law: A forgotten history of how our government segregated America. New York, NY: Liveright Publishing.

Schwab, J. (1969). The practical: A language for curriculum. The School Review, 78(1), 1-23.

Stewart, K. (2019). The power worshippers: Inside the dangerous rise of religious nationalism. New York, NY: Bloomsbury.

Stewart, K. (2020, March 27). The religious right's hostility to science is crippling our coronavirus response. The New York Times. https://www.nytimes.com/2020/03/27/opinion/coronavirus-trump-evangelica 1s.html

Taubman, P. M. (2009). Teaching by numbers: Deconstructing the discourse of standards and accountability in education. New York, NY: Routledge.

Taylor, C. (2009). The culture of confession from Augustine to Foucault: A genealogy of the 'confessing animal'. New York, NY: Routledge.

Taylor, K.-Y. (2019). Race for profit: How banks and the real estate industry undermined Black homeownership. Chapel Hill, NC: University of North Carolina Press.

Tesich, S. (1992, January 6-13). A government of lies. The Nation, 12-14.

Tyler, R. W. (1949). Basic principles of curriculum and instruction. Chicago, IL: University of Chicago Press.

Vitale, A. S. (2017). The end of policing. London: Verso.

Wiggins, G., \& McTighe, J. (2005). Understanding by design (2nd ed.). Alexandria, VA: ASCD. 
Publisher's Note Springer Nature remains neutral with regard to jurisdictional claims in published maps and institutional affiliations.

James P. Burns is an Assistant Professor of Curriculum Studies in the College of Arts, Sciences, and Education at Florida International University in Miami, Florida. Research interests include institutional power and violence in the intersections of race, gender, sexuality, and religion; peace studies; and curriculum theory. His book, Power, Curriculum, and Embodiment: Re-thinking Curriculum as Counter-Conduct and Counter-Politics, received the Outstanding Book Award for Curriculum Studies from the American Educational Research Association (AERA) in 2019. He has published in journals including: Education Policy Analysis Archives, Peace Review: A Journal of Social Justice, Journal of Curriculum Theorizing, and Journal for Critical Education Policy Studies

Christopher Cruz is a doctoral student in Teaching and Learning, with a focus on curriculum, cultural, and social studies, at Florida International University in Miami, Florida. His research interests include curriculum studies, the literary study of education, phenomenology, and liberation theology 